\title{
THE INFORMATION CHANNELS THAT MATTER: THE CASE OF SOCIAL ENTERPRISE CUSTOMERS IN LATVIA
}

\author{
Kristīne Casno ${ }^{1}$, Daina ŠĶiltere ${ }^{2}$, Biruta Sloka ${ }^{3}$ \\ University of Latvia (Latvia)
}

\begin{abstract}
Social entrepreneurship is becoming more and more popular as there is a growing share of people who would like to contribute for social enterprises and are ready to become customers of the social enterprises and in this way participate in reduction of poverty in the country and support entrepreneurship development. For social enterprise marketing communications to be effective, an understanding is necessary not only of the information channels which are most effective but also of the preferences customers hold regarding the information channels that they would like to receive information from. Purpose of research: to investigate the preferences for different information channels among customers of Latvian social enterprises. Research methods: scientific publications analysis, analysis of previous conducted research results, social enterprise customers' survey conducted by Kristīne Casno. Results of research have indicated that regular customers of social enterprises prefer such information channels as social networks, followed by television and radio.
\end{abstract}

KEYWORDS: social enterprise, information channels, decision making, social entrepreneurship, survey

JEL CODES: M14; M31; M38

DOI:

\section{Introduction}

Social entrepreneurship is becoming more and more popular as there is a growing share of people who would like to contribute for social enterprises and are ready to become customers of the social enterprises and in this way participate in reduction of poverty in the country and support entrepreneurship development. However, social enterprises operate under tight budget constraints and have limited funds available for marketing purposes. Therefore, they have to make sure they select the right communication channels for their message to reach both their existing and potential customers. Although general information on information channels and their effectiveness is available, what social enterprises usually lack is the knowledge of the actual preferences of their customers with regards to the information channels that they would like to receive the information from.

1 Kristīne Casno - research assistant at the University of Latvia Institute of Economic and Management Sciences for realisation of National Research Program, University of Latvia, Institute of Economic and Management Sciences

Scientific field: social marketing

E-mail: kristine_casno@yahoo.com

Tel. +37127836333

2 Daina Šķiltere - professor, dr.oec., University of Latvia, Department of Management Sciences

Scientific field - econometrics

E-mail: Daina.Skiltere@1u.lv

Tel. +37167034753

3 Biruta Sloka - professor dr. oec., University of Latvia, Department of Management Sciences

Scientific field - marketing

E-mail: Biruta.Sloka@lu.lv

Tel. +37129244966 
Purpose of research: to investigate the preferences for different information channels among customers of Latvian social enterprises.

Tasks of research: 1) to analyze recent research findings on social entrepreneurship development and information channel effectiveness reflected in recent scientific publications; 2) analyze the preferences of social enterprise customers with regards to information channels that they would like to receive information about social enterprises from 3 ) analyze if there are any differences in preferences among consumers with regards to their age, gender and place of residence.

Research methods: scientific publications analysis, analysis of previous conducted research results, social enterprise customers' survey conducted by Kristīne Casno. For survey data analysis indicators of descriptive statistics (indicators of central tendency or location (arithmetic means, mode, median), indicators of variability (range, variance, standard deviation, standard error of mean), cross-tabulations, testing statistical hypotheses with t-test, analysis of variance (ANOVA), as well as correlation analysis are applied.

Results of research have indicated that regular customers of social enterprises prefer to receive information from such information channels as social networks, followed by television and radio.

\section{Overview of research on social entrepreneurship}

Research world-wide has paid a lot of academic researchers' attention to several aspects of social entrepreneurship including social mission as competitive advantage with analysis of the strategic conditions of social entrepreneurship (Muñoza, Kimmitt, 2019: 859; Sekliuckiene, Kisielius, 2015: 1017; Currym, Donker, Michel, 2016: 112) as well as performance relationship to different approaches of marketing (Palacios-Marquésa, et al, 2019: 429) and innovation applications for sustainable development (Geradts, Bocken, 2019: 81) and social innovations (Ko, Liu, 2019: 781); social innovations and sustainable entrepreneurship (Satu, 2019: 551). Research results on social entrepreneurship in non-governmental organizations toward a realistic theory of social entrepreneurship has grounded on microfinance research and finding ways on selling dreams to society (Arvind, 2019: 312). As social enterprises during last years are created and developing and contributing to national economy and also to social security - often there arises a question: what will be next (Bacq, Janssen, Noel, 2019: 842). Questions on risk of social enterprises are often asked by entrepreneurs and by researchers (Sukwoong, Namil, Wonjoon, 2019: 935). Researchers and teachers state questions on readiness of university students for social entrepreneurship (Wenke, Tang, Liu, 2019: 41). Value drivers of social businesses and business model perspectives are on research agenda with finding the best possible solutions (Spieth, Schneider, Clauss, 2019: 441) and investigations of several approaches to find the best possible solution for social entrepreneurship (Martinez, Rubio, Fernandez, 2019: 456).

Analysis of approaches in achieving sustainability through Schumpeterian social entrepreneurship and the role of social enterprises are investigated by many scientists including (Rahdari, Sepasi, Moradi, 2016: 356) and on different success factors (Pal, Altay, 2019: 176). Different fields of national economy are analyzed in respect to social entrepreneurship like (Aquino, Lück, Schänzel, 2018: 28) in the field of tourism with a conceptual framework of tourism social entrepreneurship for sustainable community development including significant engagement and development of disadvantaged and underdeveloped communities sustainably through the tourism industry with suggested practical and innovative approaches. Social entrepreneurship is investigated in respect of creating value in the context of institutional complexity (Cherrier, Goswami, Ray, 2018: 251) analyzing global companies, SMEs, management differences by gender, and many other factors. In numerous research it has been indicated that women have a very special role in social entrepreneurship even giving "women as vectors of social entrepreneurship" (Kimbua, Ngoasong, 2016: 71). Different countries have different approaches for social entrepreneurship (Korstenbroek, Smets, 2019: 484; Ayman, Johnson, 2019: 531; Lall, 2019: 573). Although many aspects of social entrepreneurship have been researched, the area of social enterprise marketing has received relatively less attention from the academic researchers and is therefore an interesting field of study with practical implications for social enterprise. 
2. Relative importance and effectiveness of various information channels in marketing

The overwhelming amount of information today that people encounter makes it more and more difficult for companies to convey their marketing message to consumers effectively. In the digital era communication is changing from previously so common one-way communication to a many-to-many communication model where consumers hold a fair share of power that companies must become aware of (Klepek, Starzyczna, 2018: 501). Businesses have turned to integrated marketing communication with a deeper focus on the consumer and a unified message across all communication channels for a greater impact (Duralia, 2018: 94). Regardless of the communication channel, one must evaluate their strengths and weaknesses. For example, while television is highly effective because of the possibility to combine visuals with sound, the costs are high and it is impossible to select whom to target the message to. Direct mail, on the other hand, allows to select the audiences, but is associated with high costs and has earned a negative reputation. Radio allows audience selection as well, but is limited only to sound which diminishes the efficiency of this information channel. Using internet, including social networks, for communication of information, is a relatively low cost option which allows to select audiences but the message has to compete with millions of others in the digital networks (Kotler, Keller, 2016: 616).

Irrespective of the dominance of internet in modern digital era, consumers are still highly influenced by traditional mass media information channels (Peštek, 2012: 48). Television is found to be most efficient, print media the least efficient but internet, used separately, the second least efficient marketing communication channel. Therefore, for best results internet as a channel should be combined with traditional media (Stolyarova, Rialp, 2014: 213). Given the challenges in communication today, an in-depth understanding of the information channels that social enterprise consumers prefer to receive information from, would provide practical insights for social enterprises that could increase the effectiveness of their marketing communication.

\section{Empirical research methodology and main results}

For data collection purposes authors used quantitative research in the form of the customers' of social enterprises survey. It was distributed over a period of 2 months through social networks with support from Latvian Social Entrepreneurship Association and Latvian social enterprises. Possible respondents got invitation to participate in the survey and if the possible respondent have not filled the survey, invitation was sent in two weeks and a third time reminder was sent after four weeks. Respondents were asked a set of questions to investigate in-depth insight about the purchasing habits and opinions of Latvian social enterprise product consumers. Among other questions, the respondents were also asked to indicate their preference on a scale from 1 (would not like to receive) to 10 (would like to receive) towards receiving information about social enterprises and their offerings across various information channels.

The survey was completed by 329 respondents (the number of fully completed surveys was 224 ), $84 \%$ of them female, $16 \%$ male of whom more than $80 \%$ were of age 16-45 and held either a master's or bachelor's degree. The number of respondents who had not made any purchases of social enterprises' products or services during 2018 was only 63. Most respondents (46.8\%) had made purchases 1-4 times during 2018, $11 \%$ of respondents $-5-8$ times, $5.9 \%-9-12$ times, and $9.7 \%$ of respondents -13 times and more. Overall, consumers of Latvian social enterprise products indicated on average the highest preference for such information channels as social networks, television and radio, as reflected in Table 1. 
Table 1. Main statistic indicators of respondents,' who had made purchases from social enterprises in 2018, preference for receiving information about social enterprises across information channels

\begin{tabular}{|l|c|c|c|c|c|c|}
\hline & Printed media & E-mail & Radio & $\begin{array}{c}\text { Social } \\
\text { networks }\end{array}$ & Direct mail & Television \\
\hline Mean & 4.22 & 5.21 & 6.46 & 8.25 & 2.28 & 6.52 \\
\hline Mode & 1 & 1 & 8 & 10 & 1 & 10 \\
\hline N & 143 & 157 & 148 & 166 & 144 & 155 \\
\hline Std. Deviation & 2.929 & 3.229 & 2.651 & 2.076 & 2.218 & 3.059 \\
\hline Median & 4 & 5 & 7 & 9 & 1 & 8 \\
\hline Std. Error of Mean & 0.245 & 0.258 & 0.218 & 0.161 & 0.185 & 0.246 \\
\hline Range & 9 & 9 & 9 & 9 & 9 & 9 \\
\hline
\end{tabular}

Source: Authors' construction based on questionnaire developed by Kristīne Casno and survey conducted in 2019, evaluation scale $1-10$, where 1 - would not like to receive; 10 - would like to receive, $\mathrm{n}=329$

Social networks are clearly the most preferred means of communication about Latvian social enterprises and their offerings among existing social enterprise customers, which confirms the appealing nature of interactive internet communications.

Respondents who had not made any purchases from Latvian social enterprises during 2018 compared to those who had, indicated on average lower scores across all information channels, as reflected in Table 2, however social networks, television and radio still remain in the leading positions which suggests that aforementioned are equally optimal for communication with both existing as well as new customers.

Table 2. Main statistic indicators of respondents,' who had not made purchases from social enterprises in 2018, preference for receiving information about social enterprises across information channels

\begin{tabular}{|l|c|c|c|c|c|c|}
\hline & Printed media & E-mail & Radio & $\begin{array}{c}\text { Social } \\
\text { networks }\end{array}$ & Direct mail & Television \\
\hline Mean & 2.75 & 4.00 & 5.76 & 7.07 & 1.76 & 5.89 \\
\hline Mode & 1 & 1 & 1 & 10 & 1 & 10 \\
\hline N & 52 & 53 & 54 & 59 & 51 & 55 \\
\hline Std. Deviation & 2.848 & 3.223 & 3.174 & 2.924 & 1.807 & 3.665 \\
\hline Median & 1 & 2 & 6 & 8 & 1 & 6 \\
\hline Std. Error of Mean & 0.395 & 0.443 & 0.432 & 0.381 & 0.253 & 0.494 \\
\hline Range & 9 & 9 & 9 & 9 & 8 & 9 \\
\hline
\end{tabular}

Source: Authors' construction based on questionnaire developed by Kristīne Casno and survey conducted in 2019 , evaluation scale $1-10$, where 1 - would not like to receive; 10 - would like to receive, $\mathrm{n}=329$

Taking into account that social enterprises are usually restricted by tight financial and human resources, the understanding of frequent shoppers' communication preferences accross various information channels is of utmost importance for sustainable operations of the social enterprise. While those who made purchases from social enterprises more than 13 times during 2018 indicated on average higher scores across all information channels compared to the rest of consumer base among respondents which confirms the previously defined trend of social networks, television and radio as the most preferred means of communication, the Authors found the relatively high value of mean and mode for e-mail as information channel particularly interesting in this consumer group, as reflected in Table 3. 
Table 3. Main statistic indicators of respondents,' who had made purchases from social enterprises 13 times and more in 2018, preference for receiving information about social enterprises across information channels

\begin{tabular}{|l|c|c|c|c|c|c|}
\hline & Printed media & E-mail & Radio & $\begin{array}{c}\text { Social } \\
\text { networks }\end{array}$ & Direct mail & Television \\
\hline Mean & 4.38 & 6.17 & 6.70 & 8.48 & 2.12 & 7.25 \\
\hline Mode & 2 & 8 & $8 ; 10$ & 10 & 1 & 10 \\
\hline N & 16 & 18 & 20 & 21 & 16 & 20 \\
\hline Std. Deviation & 2.872 & 2.684 & 2.774 & 1.914 & 2.062 & 2.693 \\
\hline Median & 3.5 & 5.5 & 7.5 & 9 & 1 & 8 \\
\hline Std. Error of Mean & 0.718 & 0.633 & 0.620 & 0.418 & 0.515 & 0.602 \\
\hline Range & 9 & 9 & 8 & 7 & 8 & 8 \\
\hline
\end{tabular}

Source: Authors' construction based on questionnaire developed by Kristīne Casno and survey conducted in 2019 , evaluation scale $1-10$, where 1 - would not like to receive; 10 - would like to receive, $\mathrm{n}=329$

Correlation analysis identified a statistically significant (sig 0,006) correlation relationship which suggests that consumers who indicated a higher preference for e-mail as an information channel on average made purchases from social enterprises more often.

Table 4. Correlation analysis results (consumer shopping frequency and preference for e-mail as an information channel)

\begin{tabular}{|c|c|c|c|}
\hline \multicolumn{4}{|c|}{ Correlations } \\
\hline & & $\begin{array}{l}\text { How many times did you purchase products/ } \\
\text { services of social enterprises in } 2018 ?\end{array}$ & E-mail \\
\hline \multirow{3}{*}{$\begin{array}{l}\text { How many times did you } \\
\text { purchase products/ services of } \\
\text { social enterprises in } 2018 ?\end{array}$} & Pearson Correlation & 1 & $0,220^{* *}$ \\
\hline & Sig. (2-tailed) & & 0,006 \\
\hline & $\mathrm{N}$ & 174 & 157 \\
\hline \multirow[t]{3}{*}{ E-mail } & Pearson Correlation & $0,220^{* *}$ & 1 \\
\hline & Sig. (2-tailed) & 0,006 & \\
\hline & $\mathrm{N}$ & 157 & 157 \\
\hline
\end{tabular}

Source: Authors' construction based on questionnaire developed by Kristīne Casno and survey conducted in 2019, evaluation scale $1-10$, where 1 - would not like to receive; 10 - would like to receive, $\mathrm{n}=329$

Such results suggest that, despite rather big differences in evaluations of respondents with very different indicators of central tendency or location (arithmetic mean, mode and median) and rather big indicators of variability, e-mail as an information channel may still serve as an effective mean of communication with a high potential to bring in sales for Latvian social enterprises. Authors did not recognize any other statistically significant correlations between consumers' shopping frequency and preference for other information channels.

Authors were also interested to investigate how the patterns for the preference for receipt of information across various information differed among various consumer age (16-55) groups, as reflected in Table 5. 
Table 5. Main statistic indicators of preferences for receipt of information across different information channels in various consumer age groups

\begin{tabular}{|c|c|c|c|c|c|c|c|}
\hline \multicolumn{2}{|c|}{ Age group Statistical indicators } & Printed media & E-mail & Radio & Social networks & Direct mail & Television \\
\hline \multirow{5}{*}{$\begin{array}{l}16-25 \\
\text { years }\end{array}$} & Mean & 4.93 & 6.07 & 7.00 & 8.27 & 1.69 & 6.13 \\
\hline & $\mathrm{N}$ & 14 & 15 & 15 & 15 & 13 & 15 \\
\hline & Std. Deviation & 3.385 & 3.327 & 2.420 & 2.404 & 1.109 & 3.399 \\
\hline & Std. Error of Mean & 0.905 & 0.859 & 0.625 & 0.621 & 0.308 & 0.878 \\
\hline & Range & 9 & 9 & 8 & 9 & 3 & 9 \\
\hline \multirow{5}{*}{$\begin{array}{l}26-35 \\
\text { years }\end{array}$} & Mean & 3.97 & 5.23 & 6.47 & 8.26 & 1.89 & 6.51 \\
\hline & $\mathrm{N}$ & 60 & 65 & 64 & 70 & 62 & 68 \\
\hline & Std. Deviation & 2.531 & 3.131 & 2.714 & 2.076 & 1.812 & 3.141 \\
\hline & Std. Error of Mean & 0.327 & 0.388 & 0.339 & 0.248 & 0.230 & 0.381 \\
\hline & Range & 9 & 9 & 9 & 9 & 8 & 9 \\
\hline \multirow{5}{*}{$\begin{array}{l}36-45 \\
\text { years }\end{array}$} & Mean & 4.08 & 5.02 & 6.15 & 8.42 & 2.32 & 6.26 \\
\hline & $\mathrm{N}$ & 39 & 45 & 41 & 50 & 41 & 42 \\
\hline & Std. Deviation & 3.064 & 3.265 & 2.780 & 1.991 & 2.339 & 3.029 \\
\hline & Std. Error of Mean & 0.491 & 0.487 & 0.434 & 0.282 & 0.365 & 0.467 \\
\hline & Range & 9 & 9 & 9 & 9 & 9 & 9 \\
\hline \multirow{5}{*}{$\begin{array}{l}46-55 \\
\text { years }\end{array}$} & Mean & 4.13 & 6.24 & 6.07 & 8.24 & 3.81 & 7.18 \\
\hline & $\mathrm{N}$ & 16 & 17 & 14 & 17 & 16 & 17 \\
\hline & Std. Deviation & 2.986 & 3.364 & 2.464 & 1.985 & 2.786 & 3.005 \\
\hline & Std. Error of Mean & 0.747 & 0.816 & 0.659 & 0.481 & 0.697 & 0.729 \\
\hline & Range & 9 & 9 & 7 & 7 & 7 & 9 \\
\hline
\end{tabular}

Source: Authors' construction based on questionnaire developed by Kristīne Casno and survey conducted in 2019 , evaluation scale 1-10, where 1 - would not like to receive; 10 - would like to receive, $\mathrm{n}=329$

E-mail communication is overall most preferred by consumers of age groups 46-55 and 16-25. E-mail as an information channel is positively appreciated (score 8 and above) by $60 \%$ of consumers in the age group $16-25$ and $41.2 \%$ of consumers in the age group 46-55, leaving such age groups as $26-35$ and 36-45 behind with $32.3 \%$ and $26.7 \%$ of positive scores (score 8 and above) respectively. Radio as an information channel is most preferred by the younger consumers of age 16-25, 53.3\% of whom indicate scores of 8 and above for this information channel, followed by the age group 26-35 with $40.6 \%$ of scores 8 and above. Authors find it interesting that social networks have the highest mean indicator of 8.42 among age group of 36-45, leaving other age groups behind. It must be noted that positive scores ( 8 and above) for social networks are indicated by $82.4 \%$ of consumers in the age group of $46-55,80 \%$ of consumers in the age group $36-45$, $73.3 \%$ of consumers in the age group 16-25 and $77.1 \%$ of consumers in the age group 26-35, which makes social networks an attractive information channel for communication across all of them, especially with consumers of age 36 plus. Compared with other information channels, social networks have also received the lowest percent of scores below 3 (included) across all age groups. Direct mail is clearly the least preferred information channel across all age groups. More than $80 \%$ of consumers in all age groups, indicate scores below 3 for this information channel, except age group 46-55 years with almost 54\%. There is recognised a statistically significant correlational relationship between consumer age and consumer preference for direct mail, as evidenced by the results of correlation analysis reflected in Table 6 which data suggest that the preference for direct mail as an information channel tends to increase on average with increase of consumer age. 
Table 6. Correlation analysis results (consumer age and preference for direct mail as an information channel)

\begin{tabular}{|l|l|c|c|}
\hline \multicolumn{3}{|c|}{ Correlations } \\
\hline \multirow{3}{*}{ Age group } & Pearson Correlation & Age group & Direct mail \\
\cline { 2 - 4 } & Sig. (2-tailed) & 1 & $0,196^{*}$ \\
\cline { 2 - 4 } & $\mathrm{N}$ & 159 & 0,023 \\
\hline \multirow{3}{*}{ Direct mail } & Pearson Correlation & $0,196^{*}$ & 134 \\
\cline { 2 - 4 } & Sig. (2-tailed) & 0,023 & 1 \\
\cline { 2 - 4 } & $\mathrm{N}$ & 134 & 144 \\
\hline *. Correlation is significant at the 0.05 level (2-tailed) \\
\hline
\end{tabular}

Source: Authors' construction based on questionnaire developed by Kristīne Casno and survey conducted in 2019, evaluation scale $1-10$, where 1 - would not like to receive; 10 - would like to receive, $\mathrm{n}=329$

Television as an information channel is highly preferred (scores of 8 and above) by consumers of the age group 46-55 (58.8\% of respondents), followed by age groups $26-35$ (50\% respondents), 36-45 (47.6\% respondents) and $16-25$ ( $40 \%$ respondents). The popularity of printed media is below average. This information channel is most preferred (scores of 8 and above) by youngest consumers of age 16-25 (21.4\%; mean indicator of 4.93), followed by consumers of age 46-55 (18.8\%, mean indicator of 4.13). It must be noted that Authors find the differences in consumer preferences for various information channels across all age groups to be statistically significant, except for direct mail, as reflected in Table 7.

Table 7. ANOVA results on investigation of differences in respondent evaluations on information channels by respondent age groups

\begin{tabular}{|c|c|c|c|c|c|c|}
\hline \multicolumn{7}{|c|}{ ANOVA } \\
\hline & & $\begin{array}{l}\text { Sum of } \\
\text { Squares }\end{array}$ & $d f$ & Mean Square & $F$ & Sig. \\
\hline \multirow[t]{3}{*}{ Printed media } & Between Groups & 10.634 & 3 & 3.545 & 0.436 & 0.728 \\
\hline & Within Groups & 1017.381 & 125 & 8.139 & & \\
\hline & Total & 1028.016 & 128 & & & \\
\hline \multirow[t]{3}{*}{ E-mail } & Between Groups & 26.710 & 3 & 8.903 & 0.858 & 0.465 \\
\hline & Within Groups & 1432.508 & 138 & 10.380 & & \\
\hline & Total & 1459.218 & 141 & & & \\
\hline \multirow[t]{3}{*}{ Radio } & Between Groups & 9.833 & 3 & 3.278 & 0.456 & 0.713 \\
\hline & Within Groups & 933.988 & 130 & 7.185 & & \\
\hline & Total & 943.821 & 133 & & & \\
\hline \multirow[t]{3}{*}{ Social networks } & Between Groups & .924 & 3 & 0.308 & 0.072 & 0.975 \\
\hline & Within Groups & 635.544 & 148 & 4.294 & & \\
\hline & Total & 636.467 & 151 & & & \\
\hline \multirow[t]{3}{*}{ Direct mail } & Between Groups & 51.425 & 3 & 17.142 & 3.987 & 0.009 \\
\hline & Within Groups & 550.294 & 128 & 4.299 & & \\
\hline & Total & 601.720 & 131 & & & \\
\hline \multirow[t]{3}{*}{ Television } & Between Groups & 12.128 & 3 & 4.043 & 0.415 & 0.742 \\
\hline & Within Groups & 1343.308 & 138 & 9.734 & & \\
\hline & Total & 1355.437 & 141 & & & \\
\hline
\end{tabular}

Source: Authors' construction based on questionnaire developed by Kristīne Casno and survey conducted in 2019, evaluation scale $1-10$, where 1 - would not like to receive; 10 - would like to receive, $\mathrm{n}=329$ 
Authors were also interested to investigate if there were any differences in preference for various information channels among men and women. Overall, while women tend to prefer social networks, followed by radio and television, men are more reserved with regards to social networks as an information channel. While for men social networks still hold the highest mean indicator, their second most popular choice of communication according to mean indicators is e-mail, followed by television, as reflected in Table 8 .

Table 8. Main statistical indicators for preferences of receipt of information across various information channels by gender

\begin{tabular}{|l|l|c|c|c|c|c|c|}
\hline \multicolumn{2}{|c|}{ Gender } & $\begin{array}{c}\text { Printed } \\
\text { Media }\end{array}$ & E-mail & Radio & $\begin{array}{c}\text { Social } \\
\text { networks }\end{array}$ & Direct mail & Television \\
\hline \multirow{5}{*}{ Woman } & Mean & 4.22 & 5.14 & 6.66 & 8.41 & 2.13 & 6.65 \\
\cline { 2 - 8 } & N & 113 & 126 & 119 & 136 & 115 & 126 \\
\cline { 2 - 8 } & Std. Deviation & 2.899 & 3.249 & 2.641 & 1.930 & 2.054 & 3.078 \\
\cline { 2 - 8 } & Median & 4 & 5 & 7 & 9 & 1 & 8 \\
\hline \multirow{5}{*}{ Man } & Std. Error of Mean & 0.273 & 0.289 & 0.242 & 0.166 & 0.192 & 0.274 \\
\cline { 2 - 8 } & Range & 9 & 9 & 9 & 9 & 9 & 9 \\
\cline { 2 - 8 } & Mean & 3.65 & 6.41 & 5.13 & 7.25 & 16 & 17 \\
\cline { 2 - 8 } & Std. Deviation & 2.805 & 3.022 & 2.553 & 2.887 & 2.322 & 3.093 \\
\cline { 2 - 8 } & Median & 2 & 7 & 5 & 8 & 1 & 5 \\
\cline { 2 - 8 } & Std. Error of Mean & 0.680 & 0.733 & 0.638 & 0.722 & 0.563 & 0.750 \\
\cline { 2 - 8 } & Range & 7 & 9 & 8 & 9 & 7 & 8 \\
\hline
\end{tabular}

Source: Authors' construction based on questionnaire developed by Kristīne Casno and survey conducted in 2019 , evaluation scale $1-10$, where 1 - would not like to receive; 10 - would like to receive, $\mathrm{n}=329$

With regards to e-mail communication, $41 \%$ of men compared to $33 \%$ of women identified a score of 8 and above. The proportion of the lowest scores from 1 to 3 was also lower for men (only 24\% compared to $37 \%$ for women). The differences among men and women with regards to their preference for communication via radio was also interesting $-45 \%$ of women provided scores of 8 and above compared to $19 \%$ of males. A larger proportion of men also provided low scores of 1 to 3 for this information channel - 31\% compared to only $13 \%$ of women. Social networks, while holding the most preferred position for both genders, were still more preferred by women $-79 \%$ of women provided scores of 8 and above compared to $63 \%$ of men. While for both genders television is the third most popular choice of information channel, $51 \%$ of females provided scores of 8 and above, compared to only $35 \%$ of males, independent samples t-test confirmed statistically significant differences in preferences for such information channels as social networks and radio between men and women. 
Table 9. Results of the independent samples t-test on evaluations of different information channels by respondent's gender

\begin{tabular}{|c|c|c|c|c|c|c|c|c|}
\hline & $\begin{array}{l}\text { Levene's Test } \\
\text { for Equality of }\end{array}$ & \multicolumn{6}{|c|}{ t-test for Equality of Means } \\
\hline & & $\boldsymbol{F}$ & Sig. & $t$ & $d f$ & $\begin{array}{c}\text { Sig. } \\
\text { (2-tailed) }\end{array}$ & $\begin{array}{l}\text { Mean } \\
\text { Diff. }\end{array}$ & $\begin{array}{c}\text { Std. } \\
\text { Error } \\
\text { Diff. }\end{array}$ \\
\hline \multirow{2}{*}{ Printed media } & $\begin{array}{l}\text { Equal variances } \\
\text { assumed }\end{array}$ & 0.038 & 0.846 & 0.764 & 128 & 0.446 & 0.574 & 0.751 \\
\hline & $\begin{array}{l}\text { Equal variances } \\
\text { not assumed }\end{array}$ & & & 0.783 & 21.478 & 0.442 & 0.574 & 0.733 \\
\hline \multirow{2}{*}{ E-mail } & $\begin{array}{l}\text { Equal variances } \\
\text { assumed }\end{array}$ & 0.527 & 0.469 & -1.523 & 141 & 0.130 & -1.269 & 0.833 \\
\hline & $\begin{array}{l}\text { Equal variances } \\
\text { not assumed }\end{array}$ & & & -1.610 & 21.313 & 0.122 & -1.269 & 0.788 \\
\hline \multirow{2}{*}{ Radio } & $\begin{array}{l}\text { Equal variances } \\
\text { assumed }\end{array}$ & 0.192 & 0.662 & 2.185 & 133 & 0.031 & 1.530 & 0.701 \\
\hline & $\begin{array}{l}\text { Equal variances } \\
\text { not assumed }\end{array}$ & & & 2.242 & 19.575 & 0.037 & 1.530 & 0.683 \\
\hline \multirow{2}{*}{$\begin{array}{l}\text { Social net- } \\
\text { works }\end{array}$} & $\begin{array}{l}\text { Equal variances } \\
\text { assumed }\end{array}$ & 4.457 & 0.036 & 2.148 & 150 & 0.033 & 1.162 & 0.541 \\
\hline & $\begin{array}{l}\text { Equal variances } \\
\text { not assumed }\end{array}$ & & & 1.569 & 16.614 & 0.135 & 1.162 & 0.740 \\
\hline \multirow{2}{*}{ Direct mail } & $\begin{array}{l}\text { Equal variances } \\
\text { assumed }\end{array}$ & 0.856 & 0.357 & -0.735 & 130 & 0.464 & -0.399 & 0.543 \\
\hline & $\begin{array}{l}\text { Equal variances } \\
\text { not assumed }\end{array}$ & & & -0.671 & 19.880 & 0.510 & -0.399 & 0.595 \\
\hline \multirow{2}{*}{ Television } & $\begin{array}{l}\text { Equal variances } \\
\text { assumed }\end{array}$ & 0,008 & 0.931 & 1.779 & 141 & 0.077 & 1.415 & 0.796 \\
\hline & $\begin{array}{l}\text { Equal variances } \\
\text { not assumed }\end{array}$ & & & 1.772 & 20.516 & 0.091 & 1.415 & 0.799 \\
\hline
\end{tabular}

Source: Authors' construction based on questionnaire developed by Kristīne Casno and survey conducted in 2019, evaluation scale $1-10$, where 1 - would not like to receive; 10 - would like to receive, $\mathrm{n}=329$

It was investigated if there were any differences in preference for various information channels depending on the consumers' place of residence, reflected in Table 10. 
Table 10. Main statistical indicators for preferences of receipt of information across various information channels by consumers' place of residence

\begin{tabular}{|c|c|c|c|c|c|c|c|}
\hline \multicolumn{2}{|c|}{ Place of Residence } & $\begin{array}{c}\text { Printed } \\
\text { media }\end{array}$ & E-mail & Radio & $\begin{array}{c}\text { Social } \\
\text { networks }\end{array}$ & Direct mail & Television \\
\hline \multirow[t]{5}{*}{ Riga } & Mean & 3.79 & 5.51 & 6.32 & 8.46 & 2.11 & 6.27 \\
\hline & $\mathrm{N}$ & 72 & 77 & 74 & 83 & 73 & 79 \\
\hline & Std. Deviation & 2.653 & 3.251 & 2.639 & 2.014 & 2.052 & 3.201 \\
\hline & Std. Error of Mean & 0.313 & 0.370 & 0.307 & 0.221 & 0.240 & 0.360 \\
\hline & Range & 9 & 9 & 9 & 9 & 8 & 9 \\
\hline \multirow{5}{*}{$\begin{array}{l}\text { Municipalities } \\
\text { surrounding } \\
\text { Riga }\end{array}$} & Mean & 4.45 & 4.80 & 6.00 & 8.50 & 2.26 & 6.36 \\
\hline & $\mathrm{N}$ & 22 & 25 & 22 & 24 & 23 & 22 \\
\hline & Std. Deviation & 3.004 & 2.915 & 2.760 & 1.383 & 1.738 & 3.259 \\
\hline & Std. Error of Mean & 0.640 & 0.583 & 0.588 & 0.282 & 0.362 & 0.695 \\
\hline & Range & 9 & 9 & 9 & 4 & 6 & 9 \\
\hline \multirow{5}{*}{$\begin{array}{l}\text { Kurzeme re- } \\
\text { gion }\end{array}$} & Mean & 5.00 & 6.33 & 7.30 & 8.15 & 2.82 & 6.55 \\
\hline & $\mathrm{N}$ & 10 & 12 & 10 & 13 & 11 & 11 \\
\hline & Std. Deviation & 3.162 & 2.934 & 2.111 & 2.478 & 2.994 & 3.236 \\
\hline & Std. Error of Mean & 1.000 & 0.847 & 0.667 & 0.687 & 0.903 & 0.976 \\
\hline & Range & 9 & 9 & 6 & 9 & 9 & 9 \\
\hline \multirow{5}{*}{$\begin{array}{l}\text { Vidzeme re- } \\
\text { gion }\end{array}$} & Mean & 4.39 & 4.89 & 6.61 & 7.50 & 2.31 & 7.15 \\
\hline & $\mathrm{N}$ & 18 & 19 & 18 & 20 & 16 & 20 \\
\hline & Std. Deviation & 3.381 & 3.665 & 2.973 & 2.724 & 2.522 & 2.519 \\
\hline & Std. Error of Mean & 0.797 & 0.841 & 0.701 & 0.609 & 0.631 & 0.563 \\
\hline & Range & 9 & 9 & 9 & 9 & 8 & 9 \\
\hline \multirow{5}{*}{$\begin{array}{l}\text { Zemgale re- } \\
\text { gion }\end{array}$} & Mean & 4.80 & 5.00 & 7.17 & 8.62 & 2.00 & 7.15 \\
\hline & $\mathrm{N}$ & 10 & 11 & 12 & 13 & 10 & 13 \\
\hline & Std. Deviation & 2.898 & 3.406 & 2.725 & 1.387 & 2.211 & 2.968 \\
\hline & Std. Error of Mean & 0.917 & 1.027 & 0.787 & 0.385 & 0.699 & 0.823 \\
\hline & Range & 7 & 9 & 9 & 4 & 7 & 9 \\
\hline
\end{tabular}

Source: Authors' construction based on questionnaire developed by Kristine Casno and survey conducted in 2019, evaluation scale $1-10$, where 1 - would not like to receive; 10 - would like to receive, $\mathrm{n}=329$

Overall, printed media was rated by consumers with the average score (arithmetic mean) of 5 or below in all regions. E-mail as an information channel was most preferred in Kurzeme region, based on mean indicators. $42 \%$ of consumers provided scores of 8 or above for e-mail communication in this region, while only $28 \%$ of consumers - in municipalities surrounding Riga. Radio as an information channel is also most preferred by consumers in Kurzeme. Scores of 8 or above were provided by $60 \%$ of consumers from this region, followed by $50 \%$ of consumers from Vidzeme and $41 \%$ of consumers from Riga. Social networks as an information channel were most preferred by consumers from Kurzeme ( $85 \%$ of scores 8 and above), followed by consumers from Riga ( $82 \%$ of scores 8 and above) and consumers from Zemgale (77\% of scores 8 and above). Direct mail as an information channel was rated on average below 3 by consumers in all regions. Communication over television, compared with other regions, was slightly more preferred by consumers in Kurzeme $-64 \%$ provided scores of 8 and above, followed by $54 \%$ of scores of 8 and above in Kurzeme and $50 \%$ of scores of 8 and above in Riga and Vidzeme. However, the Authors found that the differences in preferences of receipt of information across various information channels are not statistically significant by consumers' place of residence, as reflected in Table 11. 
Table 11. ANOVA results on investigation of differences in respondent evaluations on information channels by place of residence

\begin{tabular}{|l|l|c|c|c|c|c|}
\hline \multicolumn{2}{|c|}{} & Sum of Squares & $d f$ & Mean Square & $\boldsymbol{F}$ & Sig. \\
\hline \multirow{5}{*}{ Printed media } & Between Groups & 23.762 & 4 & 5.941 & 0.719 & 0.580 \\
\cline { 2 - 7 } & Within Groups & 1049.207 & 127 & 8.261 & & \\
\cline { 2 - 7 } & Total & 1072.970 & 131 & & & \\
\hline \multirow{4}{*}{ E-mail } & Between Groups & 26.297 & 4 & 6.574 & 0.626 & 0.645 \\
\cline { 2 - 7 } & Within Groups & 1459.703 & 139 & 10.501 & & \\
\cline { 2 - 7 } & Total & 1486.000 & 143 & & & \\
\hline \multirow{5}{*}{ Social networks } & Between Groups & 19.475 & 4 & 4.869 & 0.678 & 0.608 \\
\cline { 2 - 7 } & Within Groups & 940.261 & 131 & 7.178 & & \\
\cline { 2 - 7 } & Total & 959.735 & 135 & & & \\
\hline \multirow{3}{*}{ Direct mail } & Between Groups & 17.288 & 4 & 4.322 & 1.041 & 0.388 \\
\cline { 2 - 7 } & Within Groups & 614.372 & 148 & 4.151 & & \\
\cline { 2 - 7 } & Total & 631.660 & 152 & & & \\
\cline { 2 - 7 } & Between Groups & 5.473 & 4 & 1.368 & 0.293 & 0.882 \\
\cline { 2 - 7 } & Within Groups & 598.632 & 128 & 4.677 & & \\
\cline { 2 - 7 } & Total & 604.105 & 132 & & & \\
\hline \multirow{3}{*}{ Television } & Between Groups & 18.770 & 4 & 4.693 & 0.485 & 0.746 \\
\cline { 2 - 7 } & Within Groups & 1353.478 & 140 & 9.668 & & \\
\cline { 2 - 7 } & Total & 1372.248 & 144 & & & \\
\hline
\end{tabular}

Source: Authors' construction based on questionnaire developed by Kristīne Casno and survey conducted in 2019, evaluation scale $1-10$, where 1 - would not like to receive; 10 - would like to receive, $\mathrm{n}=329$

Overall, consumers prefer to receive information about social enterprises and their offerings over social networks the most, followed by television and radio. There exist statistically significant differences in preferences among age groups for various information channels except for direct mail. There is also find statistically significant differences in preferences by gender for such information channels as social networks and radio. However, consumers do not statistically significantly differ in their preferences for information channels depending on their place of residence.

\section{Conclusions}

Latvian social enterprise consumers prefer to receive information about social enterprises and their goods and services via social networks the most, followed by television and radio. The same holds true for potential consumers of social enterprise products and services and customers, who have made purchases more often than once a month. However, customers who made purchases more often than once a month also regard email communication highly, confirmed by a statistically significant correlational relationship. This suggests that e-mail communication may have potential to increase Latvian social enterprise sales.

There are statistically significant differences in preference for various information channels across several consumer age groups, except for direct mail.

E-mail communication is most appreciated by consumers of age groups 16-25 and 46-55, radio is most preferred by consumers of age groups $16-25$ and 26-35. Social networks are most preferred by consumers of age group 46-55, followed by age group of 36-45, 16-25 and 26-35. Direct mail overall is the least preferred information channel in all age groups, however, as consumer age increases the preference for direct mail tends to increase on average, which is confirmed by a statistically significant correlational relationship. Television is most favored by consumers of age group 46-55 and 26-35.

Printed media received scores below average and is generally most preferred by the younger consumers of age 16-25, followed by age group of 46-55. While both men and women prefer to receive information via 
social networks the most, the second and third most preferred options for women are radio and television, but for men - e-mail and television. With regards such information channels as social networks and radio, there are statistically significant differences in preferences of information channel use between genders for consumption of goods and services offered by social enterprises.

Social networks, while being the most preferred choice of communication medium for both men and women, received statistically significantly higher scores from women. With regards radio, women also expressed statistically significantly more positive attitude than men. Men expressed a more pronounced dislike for this information channel providing a greater proportion of low scores (1-3) than women.

Women also indicated higher scores for television, however, men showed a higher preference for eemail communication. Authors also investigated potential differences in consumer preferences for various information channels depending on their place of residence. E-mail communication, based on comparison of arithmetic means, was most preferred by consumers in Kurzeme, followed by consumers in Riga and municipalities surrounding Riga.

Radio, based on comparison of arithmetic means, was most preferred by consumers in Kurzeme, followed by consumers in Zemgale and Vidzeme. Social networks, based on comparison of arithmetic means, were most preferred by consumers in Zemgale, followed by consumers in municipalities surrounding Riga and consumers in Riga. Direct mail was considered as less important information channel - received lowest evaluations with arithmetic mean scores below 3 (in 1-10 point scale) from consumers in all regions.

Television was most preferred information channel by consumers in Vidzeme and Zemgale, followed by consumers in Kurzeme for consumption of goods and services offered by social enterprises.

Printed media was most preferred by consumers in Kurzeme, followed by consumers in Zemgale and consumers in municipalities surrounding Riga. Although there were no statistically significant differences identified in preference for information channels depending on customers' place of residence, taking them into account may still have a positive effect on communication efficiency of Latvian social enterprises

Given the position of social networks as the most preferred information channel, it is of utmost importance for social enterprise marketing specialists to invest time and resources for quality relationship building with existing and potential customers via social networks, taking into account that social networks are more preferred by women.

It is advised for social enterprise marketing specialists to take into account the differences in preference for various information channels depending on consumer age, gender and place of residence.

E-mail communication may have potential to increase sales, especially for social enterprises from Kurzeme region with a high proportion of male customers which should be taken into account by marketing specialists.

Direct mail is the least preferred means of communication among consumers, the preference for direct mail increases with consumer age, which should be taken into account by social enterprises with consumers of older age groups.

Social networks and e-mail communication are relatively low budget options that social enterprises can and should use, the high scores consumers indicated for such traditional information channels as radio and television cannot be ignored.

The synergy effect of integrated marketing communications, support is needed from the Ministry of Welfare in the form of additional funding for radio and TV programmes and possibly advertising campaigns that would help generate greater publicity and public awareness about social enterprises and their role in promoting social inclusion, sustainable regional development and other important social and economic aspects.

\section{References}

Aquino, R. S., Lück, M., Schänzel, H. A. (2018). A conceptual framework of tourism social entrepreneurship for sustainable community development. Journal of Tourism and Hospitality Management, Vol. 37, p. 23 -32.

Arvind, A. (2019). Toward a realistic theory of social entrepreneurship (NGOs) grounded on microfinance research: Selling dreams to society. Strategic Change-Briefings in Entrepreneurial Finance, Vol. 28, No. 4, p. 301-314. 
Ayman, I., Johnson, B. (2019). Managing Organizational Paradoxes in Social Enterprises: Case Studies from the MENA Region. Voluntas, Vol. 30, No. 3, p. 516-534.

Bacq, S., Janssen, F., Noel, C. (2019). What Happens Next? A Qualitative Study of Founder Succession in Social Enterprises. Journal of Small Business Management, Vol. 57, No. 3, p. 820-844.

Cherrier, H., Goswami, H., Ray, S. (2018). Social entrepreneurship: Creating value in the context of institutional complexity. Journal of Business Research, Vol. 86, p. 245-258.

Currym, J. A., Donker, H., Michel, P. (2016). Social entrepreneurship and indigenous people. Journal of Co-operative Organization and Management, Vol. 4, No. 2, p. 108-115.

Duralia, O. (2018). Integrated Marketing Communication and Its Impact on Consumer Behavior. Studies in Business and Economics, Vol. 13, No. 2, p. 92-102.

Geradts, T. H. J., Bocken, N. M. P. (2019). Driving Sustainability-Oriented Innovation - Organizations can innovate to address environmental and social problems-but they need to build the right culture. Mit Sloan Management Review, Vol. 60, No. 2, p. 78-83.

Kimbua, A. N., Ngoasong, M. Z. (2016). Women as vectors of social entrepreneurship. Annals of Tourism Research, Vol. 60, p. 63-79.

Klepek, M., Starzyczyna, H. Marketing Communication Model for Social Networks. Journal of Business Economics and Management, Vol. 19, No. 3, p. 500-520.

Ko, W. W., Liu, G., Yusoff, W. T. W. (2019). Social Entrepreneurial Passion and Social Innovation Performance. Nonprofit and Voluntary Sector Quarterly, Vol. 48, No. 4, p 759-783.

Korstenbroek, T., Smets, P. (2019). Developing the Potential for Change: Challenging Power through Social Entrepreneurship in the Netherlands. Voluntas, Vol. 30, No. 3, p. 475-486.

Kotler, P., Keller, K. L. (2016). Marketing Management. $15^{\text {th }}$ ed. Pearson Education Limited, 708 p.

Lall, S. A. (2019). From Legitimacy to Learning: How Impact Measurement Perceptions and Practices Evolve in Social Enterprise-Social Finance Organization Relationships. Voluntas, Vol. 30, No. 3, p. 562-577.

Martinez, N. C., Rubio, B. A., Fernandez, L. A. (2019). Social Entrepreneur: Same or Different from the Rest? Voluntas, Vol. 30, No. 3, p. 443-459.

Muñoza, P., Kimmitt, J. (2019). Social mission as competitive advantage: A configurational analysis of the strategic conditions of social entrepreneurship. Journal of Business Research, Vol. 101, p. 854-861.

Pal, R., Altay, N. (2019). Identifying Key Success Factors for Social Enterprises Serving Base-of-Pyramid Markets through Analysis of Value Chain Complexities. Journal of Business Logistics, Vol. 40, No. 2, p. 161-179.

Palacios-Marquésa, D., García, M. G., Sánchez, M. M., Pilar, M., Mari, A. (2019). Social entrepreneurship and organizational performance: A study of the mediating role of distinctive competencies in marketing. Journal of Business Research, Vol. 101, p. 426-432.

Peštek, A. (2012). Managing Mass Media Influence on Consumer Buying Behavior. Interdisciplinary Management Research, Vol. 8, p. 41-50.

Rahdari, A., Sepasi, S., Moradi, M. (2016). Achieving sustainability through Schumpeterian social entrepreneurship: The role of social enterprises. Journal of Cleaner Production, Vol. 137, p. 347-360.

Satu, A. (2019). Social innovation and sustainable entrepreneurship. International Small Business Journal - Researching Entrepreneurship, Vol. 37, No. 5, p. 551-552 .

Sekliuckiene, J., Kisielius, E. (2015). Development of Social Entrepreneurship Initiatives: A Theoretical Framework. Procedia - Social and Behavioral Sciences, Vol. 213, p. 1015-1019.

Spieth, P., Schneider, S., Clauss, T. (2019). Value drivers of social businesses: A business model perspective. Long Range Planning, Vol. 52, No. 3, p. 427-444.

Stolyarova, E., Rialp, J. (2014). Synergies Among Advertising Channels: An Efficiency Analysis. Journal of Promotion Management, Vol. 20, No. 2, p. 200-218.

Sukwoong, C., Namil, K., Wonjoon, K. (2019). Are social entrepreneurs more risk-averse? Applied Economics Letters, Vol. 26, No. 11, p. 933-937.

Wenke, W., Tang, Y., Liu, Y. (2019). Can Sense of Opportunity Identification Efficacy Play a Mediating Role? Relationship Between Network Embeddedness and Social Entrepreneurial Intention of University Students. Frontiers in Psychology, Vol. 10, p. 13-42. 


\title{
SVARBŪS INFORMACINIAI KANALAI: SOCIALINES IMONĖS KLIENTŲ ATVEJO LATVIJOJE ANALIZE்
}

\author{
Kristīne Casno, Daina ŠĶiltere, Biruta Sloka \\ Latvijos universitetas (Latvija) \\ Santrauka
}

Socialinis verslumas vis populiarejja, nes daugejja žmonių, kurie norètų prisidèti prie socialinių įmonių veiklos, yra pasirengę tapti socialinių ịmonių klientais ir taip dalyvauti, siekdami mažinti skurdą šalyje bei remti verslumo plètrą.

Norint, kad socialinių įmonių rinkodaros komunikacija būtų veiksminga, reikia ne tik atrasti veiksmingiausius informacijos kanalus, bet ir suprasti, kokiais prioritetiniais informaciniais kanalais klientai naudojasi, iš kurių kanalų norètų gauti informacijos.

Tyrimu siekta ištirti Latvijos socialinių įmonių klientų informacinių kanalų pasirinkimą. Tyrimo metodai: mokslinių publikacijų analize, ankstesnių tyrimų rezultatų analizè. Tyrimo rezultatai atskleide, kad nuolatiniai socialinių įmonių klientai renkasi tokius informacijos kanalus kaip socialiniai tinklai, tada televizija ir radijas. Tas pats pasakytina ir apie potencialius socialinių ịmonių produktų bei paslaugų vartotojus ir klientus, kurie pirko dažniau nei kartą per mėnesị. Klientai, kurie pirko dažniau nei kartą per mènesį, taip pat labai vertina bendravimą el. paštu, tai patvirtina statistiškai reikšmingas ryšys. Taigi bendravimas el. paštu gali didinti Latvijos socialinių įmonių pardavimus. Ryšį el. paštu labiausiai vertina 16-25 ir 46-55 metų vartotojai, radiją paprastai renkasi 16-25 ir 26-35 metų vartotojai. Socialinius tinklus labiausiai mégsta 46-55 metų amžiaus vartotojai, mažiau -36-45, 16-25 ir 26-35 metų grupès. Tiesioginis paštas apskritai yra mažiausiai pageidaujamas informacijos kanalas visose amžiaus grupėse, tačiau, atsižvelgiant į tai, kad vyresni vartotojai vis tiek naudojasi paštu, kaip informacijos kanalo jo visiškai atsisakyti negalima, tai patvirtina statistiškai reikšmingas koreliacinis ryšys. Televiziją labiausiai mėgsta 46-55 ir 26-35 metų amžiaus vartotojai. Socialiniai tinklai ir bendravimas el. paštu yra mažo biudžeto priemonès, kuriomis gali ir turètų naudotis socialinès įmonès, tiesa, nereikètų ignoruoti ir aukšto lygio vartotojų, nurodytų tokiems tradiciniams informacijos kanalams kaip radijas ir televizija.

PAGRINDINIAI ŽODŽIAI: socialine įmoné, informacijos kanalai, sprendimu prièmimas, socialinis verslumas, apklausa.

JEL KLASIFIKACIJA: M14; M31; M38.

Received: 2019-08-21

Revised:2019-09-14

Accepted:2019-10-01 